\title{
Pengaruh Kualitas Pelayanan Administrasi Akademik Terhadap Kepuasan Mahasiswa Politeknik Negeri Bandung
}

\author{
Maya Setiawardani ${ }^{1 *}$ \\ ${ }^{1}$ Jurusan Administrasi Niaga, Politeknik Negeri Bandung, Indonesia
}

\begin{abstract}
:
Service is an effort made to the customer to meet customer expectations. While the quality of service as an effort to meet the needs and desires of consumers and the accuracy of delivery in counterbalance consumer expectations. Bandung State Polytechnic is a vocational education institution that prepares its graduates ready to work. In achieving these objectives, it should be supported by the service of academic administration of quality to the needs and desires of students fulfilled. This study aims to illustrate how the quality of academic services according to student perceptions, describes the level of satisfaction of students, and whether there is a positive and significant influence between the quality of academic administration services there is student satisfaction. The results of this study found that the overall quality of academic administration services have been good, and student satisfaction is also good. The quality of academic administration services has a positive and significant impact on student satisfaction. Nevertheless, the quality of service still needs to be improved again such as hospitality and discipline officers, the availability of flow/chart of each service and availability of LCD projector. In addition, the overall quality of service needs to be improved again into excellent service.
\end{abstract}

Keywords: service quality, student satisfaction, academic administration

\begin{abstract}
Abstrak:
Layanan adalah upaya yang dilakukan kepada pelanggan untuk memenuhi harapan pelanggan. Sedangkan kualitas layanan sebagai upaya untuk memenuhi kebutuhan dan keinginan konsumen dan ketepatan pengiriman dalam mengimbangi harapan konsumen. Politeknik Negeri Bandung adalah lembaga pendidikan kejuruan yang mempersiapkan lulusannya siap bekerja. Dalam mencapai tujuan ini, harus didukung oleh layanan administrasi akademik yang berkualitas terhadap kebutuhan dan keinginan siswa yang terpenuhi. Penelitian ini bertujuan untuk menggambarkan bagaimana kualitas layanan akademik menurut persepsi siswa, menggambarkan tingkat kepuasan siswa, dan apakah ada pengaruh positif dan signifikan antara kualitas layanan administrasi akademik ada kepuasan siswa. Hasil penelitian ini menemukan bahwa secara keseluruhan kualitas layanan administrasi akademik sudah baik, dan kepuasan siswa juga baik. Kualitas layanan

*Email korespondensi:

Maya Setiawardani

mayaswardani@gmail.com
\end{abstract}


administrasi akademik memiliki dampak positif dan signifikan terhadap kepuasan siswa. Namun demikian, kualitas layanan masih perlu ditingkatkan lagi seperti petugas perhotelan dan disiplin, ketersediaan aliran/grafik dari masing-masing layanan dan ketersediaan proyektor LCD. Selain itu, kualitas layanan secara keseluruhan perlu ditingkatkan lagi menjadi layanan yang sangat baik.

Kata Kunci: kualitas layanan, kepuasan siswa, administrasi akademik

\section{PENDAHULUAN}

Menurut Kotler dan Armstrong (2012: 214) service merupakan "Any act or performance that one party can offer another that is essentially intangible and does not result in the ownership of anything”, artinya bahwa jasa atau pelayanan merupakan suatu aktivitas, manfaat, atau kepuasan yang ditawarkan kepada pelanggan dan pada dasarnya tidak berwujud dan tidak mengakibatkan suatu kepemilikan apapun. Jadi jasa atau pelayanan merupakan suatu upaya atau aktivitas yang bersifat intangible baik berupa interaksi maupun pemberian performa terbaik yang dilakukan oleh perusahaan kepada pelanggan guna memenuhi harapan pelanggan.

Berdasarkan pernyataan di atas, maka pelayanan yang diberikan harus dapat memenuhi kebutuhan pelanggan yang selanjutnya akan memberikan kepuasan bagi pelanggan tersebut.

Politeknik Negeri Bandung (Polban) merupakan institusi pendidikan vokasi yang mempersiapkan lulusannya untuk siap bekerja. Polban tergolong institusi pendidikan yang cukup besar yang memiliki 10 jurusan dan 38 program studi, dengan total mahasiswanya sekitar 5438 orang. Dalam mempersiapkan lulusannya untuk siap bekerja, maka kegiatan pembelajarannya pun dikondisikan sedemikian rupa agar para lulusan dapat dengan mudah menyesuaikan diri di tempat kerjanya. Kegiatan pembelajaran mahasiswa Polban dilakukan sekitar 40 jam per minggu selama 5 hari. Hal ini, menggambarkan bahwa kegiatan pembelajaran di Polban cukup padat.

Dalam pelaksanaan proses pembelajaran perlu didukung oleh pelayanan administasi akademik yang baik agar dapat terlaksana dengan lancar dan baik sehingga menghasilkan luaran yang baik pula. Pelayanan administrasi akademik sangat penting peranannya dalam keberhasilan proses pendidikan. Pelayanan administrasi akademik yang baik akan memperlancar proses pembelajaran mahasiswa sehingga berhasil dengan baik, dan hal ini memberikan kepuasan kepada mahasiswa. Di samping itu, hal ini juga dapat memberikan citra yang baik bagi institusi. Hal ini selaras dengan pendapat Shauchenka \& Eugenia (2010) student satisfaction has become vital in helping universities move toward development and excellence; universities must listen to students to improve the worth and quality of student services.

Namun demikian, berdasarkan wawancara dari sebagian mahasiswa masih mengeluhkan pelayanan yang diberikan petugas, antara lain:

1. Keramahtamahan petugas yang masih kurang, mahasiswa yang datang ke kantor BAAK tidak disamput salam dan senyuman. Mahasiswa sebagai konsumen 
kurang merasa diperhatikan dan dibantu.

2. Proses birokrasi yang panjang dan lambat. Prosedur pelayanan melalui tahapan yang panjang dan dilakukan dengan lambat sehingga penyelesaian suatu kegiatan memerlukan waktu yang lama.

3. Jam kerja petugas tidak sesuai dengan jadwal yang telah ditentukan. Petugas sering terlambat datang dan juga terlalu awal istirahat, di lain pihak mahasiswa tidak memiliki banyak waktu karena padatnya kuliah sehingga proses pelayanan menjadi terhambat.

4. Cara kerja petugas kurang sistematis, efisien, dan efektif, seperti dalam pengelolaan arsip sehingga ketika arsip itu dicari memerlukan waktu yang lama.

5. Pelayanan peralatan dan fasilitas penunjang pembelajaran masih kurang baik, seperti kurangnya LCD projector dan perawatan peralatan yang lambat sehingga sebagian LCD projector tidak berfungsi.

Berdasarkan uraian di atas, maka penelitian ini berjudul "Pengaruh kualitas pelayanan administrasi terhadap kepuasan mahasiswa Politeknik Negri Bandung”.

\section{Tujuan Penelitian}

Penelitian ini dimaksudkan untuk memperoleh data serta membahas permasalahan mengenai kualitas pelayanan administrasi akademik terhadap kepuasan mahasiswa Politeknik Negeri Bandung. Oleh sebab itu, maka tujuan penelitian ini adalah untuk mengetahui:

1. Kualitas pelayanan administrasi akademik Polban

2. Tingkat kepuasan mahasiswa Polban
3. Pengaruh kualitas pelayanan terhadap kepuasan mahasiswa Polban

\section{LANDASAN TEORI}

Kualitas Pelayanan

Kualitas (Tjiptono, 2008) merupakan kombinasi dari sifat dan karakteristik, sehingga sejauh mana keluhan dapat terpenuhi oleh kebutuhan pelanggan atau menilai seberapa jauh sifat dan karakteristik itu dapat memenuhi kebutuhannya. Sedangkan menurut Kotler dan Keller (2009), quality is the totally of futures and characteristics of a product or services that bear on its ability to satisfy statet or implies needs (kualitas adalah masa depan dan karakteristik produk atau layanan yang sesuai dengan kemampuannya untuk memenuhi atau menyiratkan kebutuhan). Jadi kualitas itu yang berjangka dan karakter dari sebuah produk atau jasa yang berpengaruh kepada kemampuannya untuk memuaskan kebutuhan yang dinyatakan atau yang tersirat. Pendapat lain dari Garvin dan Timpe (dalam Alma 2011) yang menyatakan bahwa kualitas adalah keunggulan yang dimiliki oleh produk tersebut. Sedangkan kualitas dari sudut pandang konsumen adalah hal yang mempunyai ruang lingkup tersendiri yang berbeda dengan kualitas dalam pandangan produsen saat mengeluarkan suatu produk yang biasa dikenal kualitas sebenarnya.

Berdasarkan beberapa definisi di atas, maka dapat disimpulkan bahwa kualitas merupakan suatu kondisi dinamis atau karakter dari sebuah produk atau jasa yang memenuhi atau melebihi harapan.

Hal yang paling penting dalam suatu usaha adalah kualitas pelayanan yang diberikan kepada pelanggan akan merasa puas jika pelayanan yang diberikan sangat 
baik. Menurut Kotler (dalam Mardikawati dan Farida, 2011) bahwa pelayanan merupakan aktivitas atau tindakan yang ditawarkan oleh setiap pihak lain yang pada dasarnya tidak berwujud dan tidak mengakibatkan kepemilikan apapun. Sedangkan Daryanto dan Ismanto (2004) mengemukakan bahwa pelayanan yang baik adalah pelayanan yang memberikan jasa kepada masyarakat (customer) sesuai standar yang diberikan sehingga orang yang dilayani merasa gembira, puas, dan senang.

Berdasarkan beberapa pendapat di atas, maka dapat disimulkan bahwa pelayanan adalah setiap kegiatan atau aktivitas yang ditawarkan oleh perusahaan sesuai dengan standar yang ada dan dapat memenuhi kebutuhan pelanggan sehingga pelanggan merasa puas dan senang.

Kualitas pelayanan merupakan hal penting yang harus diperhatikan dalam pelayanan. Menurut Ibrahim (2008) bahwa kualitas pelayanan merupakan suatu kondisi dinamis yang berhubungan dengan produk, jasa, manusia, proses, dan lingkungan dimana penilaian kualitasnya ditentukan pada saat terjadinya pemberian pelayanan. Sedangkan Gronross (dalam Irawan 2012) berpendapat bahwa kualitas pelayanan adalah hasil persepsi perbandingan harapan pelanggan dengan kinerja aktual layanan.

Berdasarkan pendapat di atas, maka dapat disimpulkan bahwa kualitas pelayanan adalah suatu kondisi atau persepsi konsumen terhadap pemberian pelayanan antara yang diharapkan dengan kenyataan yang diterimanya. Pelayanan dalam hal ini diartikan sebagai jasa atau service yang disampaikan oleh pemilik jasa berupa kemudahan, kecepatan, hubungan, kemampuan, dan keramahtamahan yang ditujukan melalui sikap dan sifat dalam memberikan pelayanan guna mencapai kepuasan konsumen/pelanggan.

\section{Dimensi Kualitas Pelayanan}

Dari beberapa pendapat tentang pengukuran kualitas pelayanan, menurut Zeithaml (dalam Sitorus 2009) yang paling tepat digunakan dalam penelitian ini dan teori ini paling banyak digunakan untuk mengukur kualitas pelayanan terebut. Kualitas pelayanan dapat diukur dari lima dimensi, yaitu:

1. Tangible (Berwujud), tersedianya fasilitas fisik, perlengkapan dan sarana komunikasi, dan lain-lain yang dapat dan harus ada dalam proses jasa.

2. Empathy (empati), yang meliputi sikap kontak personel maupun perusahaan untuk memahami kebutuhan maupun kesulitan, konsumen, komunikasi yang baik, perhatian pribadi, kemudahan dalam melakukan komunikasi atau hubungan.

3. Reliability (kehandalan), yaitu kemampuan untuk memberikan pelayanan yang dijanjikan dengan tepat (accurately) dan kemampuan untuk dipercaya (dependably), terutama memberikan jasa secara tepat waktu, dengan cara yang sama sesuai dengan jadwal yang telah dijanjikan dan tanpa melakukan kesalahan setiap kali.

4. Responsiveness (daya tanggap), yaitu kemauan atau keinginan para karyawan untuk membantu dan memberikan jasa yang dibutuhkan konsumen

5. Assurance (jaminan), meliputi pengetahuan, kemampuan, ramah, sopan, dan sifat dapat dipercaya dari 
kontak personel untuk menghilangkan sifat keraguan konsumen dan merasa terbebas dari bahaya dan risiko.

\section{Kualitas Pelayanan Administrasi Akademik}

Administrasi akademik adalah suatu rangkaian kegiatan atau keseluruhan proses pengendalian usaha kerjasama sejumlah orang untuk mencapai tujuan yang telah ditetapkan sebelumnya secara berencana dan sistematik yang diselenggarakan dalam lingkungan pendidikan formal (Nawawi dalam Daryanto, 2010). Oleh sebab itu, kualitas pelayanan administrasi akademik merupakan perbandingan antara tingkat layanan administrasi akademik dengan harapan mahasiswa.

Adapun jasa layanan yang diberikan oleh administrasi akademik dapat berupa pendaftaran ulang mahasiswa, KRS, permohonan pembayaran SSP terlambat, penjadwalan kuliah, permohonan suratmenyurat, pengurusan traskrip nilai, permohonan bea siswa, pendaftaran wisuda dan pengurusan ijazah, dan fasilitas yang dipelukan dalam proses pembelajaran.

\section{Kepuasan Pelanggan}

Kepuasan adalah perasaan senang atau kecewa seseorang dengan membandingkan kinerja atau hasil suatu produk yang dirasakan terhadap harapannya (Kotler dalam Kaura, 2015). Sedangkan Yi dan La (dlam Osotimehin, 2015) ada dua konsep umum mengenai kepuasan yaitu kepuasan transaksi spesifik dan kepuasan kumulatif. Kepuasan transaksi spesifik merupakan evaluasi pelanggan atas pengalamannya terhadap layanan tertentu. Sedangkan kepuasan kumulatif mengacu kepada keseluruhan evaluasi pelanggan terhadap pengalamannya dalam mengunakan suatu jasa hingga saat ini.

Menurut Shauchenka \& Eugenia (2010) student satisfaction has become vital in helping universities move toward development and excellence; universities must listen to students to improve the worth and quality of student services. Selain itu, menurut Khan \& Fasih (2014: 348)

"The satisfaction of the customers is a very much important factor that not only forces the customers to remain loyal with the organization but also proves as a marketing mechanism through which other people are attracted towards the organization. The word of mouth of a satisfied customer probability has more worth than any other advertising channel."

Berdasarkan pendapat tersebut dapat disimpulkan bahwa kepuasan pelanggan sangat penting perannya, terutama dalam membangun loyalitas mahasiswa kedepannya. Bahkan dengan terciptanya kepuasan, hal tersebut bisa menciptakan mekanisme marketing melalui word of mouth yang tentunya akan menguntungkan institusi.

\section{Hubungan Antara Kualitas Pelayanan Administrasi Akademik dengan Kepuasan Pelanggan}

Pelangggan akan memiliki harapan mengenai bagaimana produk tersebut seharusnya berfungsi (performance expectation) dan harapan tersebut adalah standar kualitas yang akan dibandingkan dengan fungsi atau kualitas produk yang sesungguhnya dirasakan pelanggan (actual performance). Berdasarkan pendapat para ahli yaitu TSE dan Wilton (dalam Tjiptono, 2008) merumuskan sebagai berikut: 
Kepuasan pelanggan $=\mathrm{f}($ expectations, perceived performance)

Tjiptono, Chandra dan Adriana (2008) juga mengemukakan bahwa kualitas produk yang dirasakan oleh pelanggan akan menentukan persepsi pelanggan terhadap kinerja produk yang akan berdampak pada kepuasan pelanggan.

\section{Kerangka Pemikiran}

\begin{tabular}{|l|}
\hline Variabel X \\
Kualitas Layanan: \\
Reliability \\
(Kehandalan) \\
Responsiveness \\
(Daya Tanggap) \\
Assurance \\
(Jaminan) \\
Emphaty (Empati) \\
Tangible \\
(Bukti Fisik)
\end{tabular}$\rightarrow$ Kariabel Y

\section{Gambar 1.1. Kerangka Pemikiran} Sumber: Data olahan (2017)

\section{Hipotesis}

Adapun rumusan hipotesis dalam penelitian ini adalah sebagai berikut:

$\mathrm{H}_{\mathrm{o}}$ : Tidak terdapat pengaruh positip dan signifikan antara kualitas pelayanan administrasi akademik terhadap kepuasan mahasiswa.

$\mathrm{H}_{\mathrm{a}}$ : Ada pengaruh yang positip dan signifikan antara kualitas pelayanan administrasi akademik terhadap kepuasan mahasiswa.

\section{METODE PENELITIAN}

Penelitan ini adalah penelitian deskriptif kuantitatif yang terdiri dari dua variabel, yaitu variabel kualitas pelayanan administrasi akademik sebagai variabel bebas (X), sedangkan variabel kepuasan mahasiswa sebagai varial terikat (Y). Instrumen penelitian yang digunakan adalah kuesioner dengan skala pengukuran Likert dengan nilai rentangan 1 sampai dengan 4, dan ditunjang dengan hasil obervasi dan wawancara.

Populasi dalam penelitian ini adalah semua mahasiswa Politeknik Negeri Bandung program pendidikan Diploma III, Diploma IV, dan program pendidikan Magister Terapan yang berjumlah 5438 orang (PSI tahun 2015/2016). Sedangkan penarikan sampelnya menggunakan rumusnya Yamame (dalam Rakhmat 2004) dengan tingkat kepercayaan $10 \%$, dan didapat 100 orang responden.

Data yang terkumpul diolah dengan menggunakan SPSS for Windows versi 20.0. Metode analisis data yang digunakan adalah uji validitas dan reliabilitas, analisis deskriptif, analisis korelasi, dan analisis regresi.

\section{HASIL DAN PEMBAHASAN}

Hasil dari uji validitas dan reliabilitas terhadap instrumen penelitian ini adalah valid dan reliabel. Berdasarkan hasil uji normalitas, uji heteroskedastisitas dan uji linearitas memenuhi syarat untuk diolah lebih lanjut.

\section{Analisis Deskriptif}

Metode ini digunakan untuk mendeskripsikan kualitas pelayanan administrasi akademik dan kepuasan mahasiswa.

\section{Deskripsi Variabel Kualitas Pelayanan}

Berdasarkan tabel 1 dapat diketahui bahwa nilai rata-rata kualitas pelayanan administrasi akademik adalah sebesar 2,73. Nilai 2,73 tersebut berada pada interval 2,52 
- 3,27 yang menyatakan bahwa kualitas pelayanan dapat dikategorikan baik. Nilai standar deviasi variabel kualitas pelayanan sebesar $11,83 \%$ (< 20\%). Hal ini dapat disimpulkan bahwa semua responden memberikan jawaban yang relatif sama bahwa kualitas pelayanan administrasi akademik yang diberikan Polban sudah baik. Dari kelima dimensi dari variabel kualitas pelayanan, dimensi assurance merupakan dimensi yang dinilai tinggi kinerjanya oleh para responden dengan nilai mean sebesar 2,83. Sedangkan dimensi responsiveness merupakan dimensi yang dinilai paling rendah kinerjanya oleh para responden dengan nilai mean sebesar 2,53, bahkan ada satu pernyataan yang memiliki jawaban buruk. Satu jawaban buruk lainnya berada di dimensi tangibles.

Tabel 1. Deskiptif Variabel Kualitas

\begin{tabular}{|c|c|c|c|c|}
\hline \multicolumn{5}{|c|}{ Pelayanan } \\
\hline $\begin{array}{l}\text { Dimensi/ } \\
\text { Variabel }\end{array}$ & Min & $\operatorname{Max}$ & Mean & $S D$ \\
\hline $\begin{array}{l}\text { Dimensi } \\
\text { Tangibles }\end{array}$ & 2 & 4 & 2.82 & 0.400 \\
\hline $\begin{array}{l}\text { Dimensi } \\
\text { Responsiveness }\end{array}$ & 1 & 4 & 2.53 & 0.463 \\
\hline $\begin{array}{l}\text { Dimensi } \\
\text { Reliability }\end{array}$ & 2 & 4 & 2.73 & 0.438 \\
\hline $\begin{array}{l}\text { Dimensi } \\
\text { Emphaty }\end{array}$ & 2 & 4 & 2.80 & 0.411 \\
\hline $\begin{array}{l}\text { Dimensi } \\
\text { Assurance }\end{array}$ & 2 & 4 & 2.83 & 0.446 \\
\hline \begin{tabular}{|l|} 
Kualitas \\
Pelayanan
\end{tabular} & 2 & 4 & 2.73 & 0.323 \\
\hline
\end{tabular}

Sumber: Hasil Olah Data SPSS (2017)

\section{Deskripsi Variabel Kepuasan Pelanggan}

Berdasarkan hasil analisis data, berikut adalah gambaran tentang variabel kepuasan pelanggan/mahasiswa yang diukur menggunakan tiga pernyataan. Berdasarkan tabel 2 dapat diketahui bahwa nilai rata-rata kepuasan pelanggan/mahasiswa terhadap pelayanan administrasi akademik Polban adalah sebesar 2,66. Nilai tersebut berada pada rentang 2,52 - 3,27 sehingga dapat dikategorikan baik. Standar deviasi pada variabel ini menunjukkan nilai variansi sebesar $17,25 \% \quad(<20 \%)$. Hal ini dapat disimpulkan bahwa semua responden memiliki jawaban yang relatif sama terhadap kepuasan yang diberikan Polban dalam hal pelayanan administrasi akademik sudah baik. Pernyataan "Bila tingkat kepuasan dinilai dengan angka 1 s.d. 4, maka Saudara berada di nomor berapa?'memiliki nilai mean yang tertinggi, dan pernyataan "Saya percaya bahwa menggunakan pelayanan administrasi akademik biasanya/umumnya merupakan pengalaman yang memuaskan" memiliki nilai mean terendah.

Tabel 2. Deskriptif Variabel Kepuasan Pelanggan

\begin{tabular}{|l|c|c|c|c|}
\hline $\begin{array}{c}\text { Item } \\
\text { Pernyataan }\end{array}$ & Min & Max & Mean & SD \\
\hline Kepuasan 1 & 1 & 4 & 2.65 & 0.592 \\
\hline Kepuasan 2 & 1 & 4 & 2.65 & 0.539 \\
\hline Kepuasan 3 & 1 & 4 & 2.69 & 0.563 \\
\hline $\begin{array}{l}\text { Kepuasan } \\
\text { Pelanggan }\end{array}$ & $\mathbf{2}$ & $\mathbf{4}$ & $\mathbf{2 . 6 6}$ & $\mathbf{0 . 4 5 9}$ \\
\hline
\end{tabular}

Sumber: Hasil Olah Data SPSS (2017)

\section{Analisis Korelasi Sederhana}

Analisis korelasi ini digunakan untuk mengetahui keeratan hubungan dan arah hubungan yang terjadi antara variabel kualitas pelayanan terhadap kepuasan pelanggan/mahasiswa. Berdasarkan hasil pengolah didapat bahwa nilai korelasi antara variabel kualitas pelayanan dan kepuasan pelanggan sebesar 0,659 yang berada pada interval $+0,50$ s.d $+0,69$, yang berarti terdapat hubungan positif yang kuat antara 
kualitas pelayanan dengan kepuasan pelanggan. Hal ini menunjukkan bahwa semakin baik kualitas pelayanan yang dirasakan oleh pelanggan/mahasiswa, maka tingkat kepuasan pelanggan/mahasiswa pun akan semakin baik.

\section{Regresi Linear Sederhana}

Analisis regresi digunakan untuk mengetahui seberapa besar pengaruh kualitas pelayanan terhadap kepuasan pelanggan/mahasiswa. Berdasarkan pengolahan dapat diketahui nilai konstanta (a) sebesar 0,831 dengan koefisien regresi (b) sebesar 0,130. Oleh karena itu, persamaan regresi yang dapat diperoleh dalam penelitian ini adalah:

\section{$\mathbf{Y}=\mathbf{0 , 8 3 1 + 0 , 1 3 0 X}$}

Jika kualitas pelayanan sama dengan nol $(\mathrm{X}=0)$ atau tidak ada kepuasan pelanggan, maka kepuasan pelanggan hanya sebesar 0.831. Jika kualitas pelayanan mengalami kenaikan satu satuan, maka kepuasan pelanggan akan mengalami kenaikan sebesar 0,130 satuan. Hal ini menunjukkan bahwa kualitas pelayanan berpengaruh positif terhadap kepuasan pelanggan/mahasiswa.

\section{Koefisien Determinasi}

Koefisien determinasi ini untuk melihat kemampuan variabel independen yaitu kualitas pelayanan (X) dalam menerangkan variabel kepuasan pelanggan (Y). Apabila $R$ square mendekati angka 1, maka variabel independen tersebut memberikan hampir semua informasi yang dibutuhkan untuk memprediksi variasi variabel dependen. Berdasarkan hasil perhitungan diketahui $\mathrm{R}$ square (koefisien determinasi) sebesar $0,434(43,4 \%)$ yang merupakan hasil kuadrat dari 0,659 . Hal ini menunjukkan bahwa sebesar $43,4 \%$ kepuasan pelanggan bisa dijelaskan oleh kualitas pelayanan, sedangkan sisanya $(56,6 \%)$ disebabkan oleh faktor-faktor lain.

\section{Uji Hipotesis}

Uji hipotesis yang digunakan dalam penelitian ini adalah uji $F$ dan uji t. Uji $F$ digunakan untuk menguji variabel-variabel bebas secara bersama-sama terhadap variabel terikat. Berdasarkan hasil perhitungan didapat angka significant pada kolom Sig. sebesar 0,000 atau kurang dari nilai probabilitasnya $0,05(5 \%)$. Apabila dilihat dari nilai $\mathrm{F}$ hitung $\left(\mathrm{F}_{0}\right)$ yang terlihat pada kolom $\mathrm{F}$ yang besarnya 75,254 dengan menggunakan tingkat signifikansi 0,05 serta $\mathrm{df}_{1}:(\mathrm{k}-1)=2-1$ dan $\mathrm{df}_{2}: 100-2=98$, maka diperoleh $F$ tabel $\left(F_{1}\right)$ sebesar 3,94 yang berarti bahwa nilai $F_{0} \geq F_{1}$ yaitu $75,254 \geq$ 3,94 .

Mengacu pada interpretasi hasil uji statistik F menurut Arikunto (2010), jika kriteria $F_{0} \geq F_{1}$ dengan taraf signifikansi 5\% maka interpretasinya adalah $\mathrm{H}_{\mathrm{o}}$ ditolak dan $\mathrm{H}_{\mathrm{a}}$ diterima. Hal ini menunjukkan bahwa kualitas pelayanan berpengaruh positif dan signifikan terhadap kepuasan pelanggan/mahasiswa.

Uji t digunakan untuk mengetahui ada atau tidaknya pengaruh antara kualitas pelayanan $(\mathrm{X})$ terhadap kepuasan pelanggan (Y). Berikut ini merupakan dasar pengambilan keputusan pada uji t dengan tingkat signifikansi 0,05 dengan hasil yang didapat adalah sebagai berikut:

1. Jika tingkat signifikansi $t_{\text {hitung }}>$ 0,05 atau $t_{\text {hitung }}<t_{\text {table, }}$, maka $\mathrm{H}_{\mathrm{o}}$ diterima.

2. Jika tingkat signifikansi $t_{\text {hitung }}<$ 0,05 atau $t_{\text {hitung }}>t_{\text {table, maka }} \mathrm{H}_{\mathrm{o}}$ ditolak.

Berdasarkan hasil perhitungan, didapat nilai t hitung sebesar 8,675. Dengan 
rumus df: $(\mathrm{n}-\mathrm{k}-1)=100-1-1=98$, maka diperoleh $t_{\text {tabel }}$ sebesar 1,984. Berdasarkan data tersebut diperoleh nilai thitung yang lebih besar dari $t_{\text {tabel }}(8,675>1,984)$. Angka significant pada kolom Sig. adalah 0,000. Nilai tersebut lebih kecil dibandingkan dengan nilai probabilitas yang nilainya 0,05 (5\%) atau dapat dilambangkan bahwa 0,000 $<0,05$. Berdasarkan pendapat Priyatno (2013) bahwa jika kriteria $t_{\text {hitung }}>t_{\text {tabel }}$ dan tingkat signifikansi $t_{\text {hitung }}<0,05$, maka kesimpulannya adalah $\mathrm{H}_{\mathrm{o}}$ ditolak dan $\mathrm{H}_{\mathrm{a}}$ diterima. Dengan demikian, dapat disimpulkan bahwa kualitas pelayanan (X) memiliki pengaruh yang positif dan signifikan terhadap kepuasan pelanggan/mahasiswa (Y).

\section{Pembahasan}

\section{Kualitas Pelayanan}

Pembahasan ini untuk menjawab tujuan penelitian yang pertama, yaitu tingkat kualitas pelayanan administrasi akademik yang diberikan Polban.

Berdasarkan Tabel 1 nilai rata-rata kualitas pelayanan yang dinilai oleh pelanggan yakni mahasiswa Polban adalah sebesar 2,73. Nilai tersebut berada pada rentang 2,52-3,26 sehingga kualitas layanan dapat dikategorikan baik. Selain itu, bila dilihat dari nilai standar deviasinya, variabel ini memiliki nilai variansi dibawah $20 \%$ sehingga dapat disimpulkan bahwa responden menjawab pernyataan pada variabel ini dengan jawaban yang sama.

Menurut Asaduzzaman et al. (2013: 129) "service quality in educational industry is defined on the basis of students overall evaluation on the services they received which is part of their educational experience". Di dunia pendidikan, kualitas layanan didefinisikan berdasarkan evaluasi keseluruhan pengalaman mahasiswa terhadap layanan yang mereka terima, yang merupakan bagian dari pengalaman pendidikan mereka. Kualitas layanan dalam dunia pendidikan sangat penting untuk diperhatikan. Menurut Daunorienė dalam Saleh (2016: 41) "service quality is a vital factor in the success of institutions because it affects their survival, cost, profitability, and clients' contentment. Nowadays, quality is one of the most critical issues at all universities". Bahkan menurut Hanaysha et al. (2012), di Malaysia baik institusi pendidikan tinggi negeri maupun swasta berusaha untuk memberikan layanan yang berkualitas kepada mahasiswamahasiswanya secara konsisten. Hal itu dimaksudkan untuk mengembangkan dan memelihara reputasi institusi mereka. Berdasarkan hal tersebut, dimensi-dimensi kualitas pelayanan menjadi bagian yang tidak boleh diabaikan oleh setiap institusi pendidikan.

Menurut Zeithaml (dalam Sitorus 2009), terdapat lima dimensi kualitas pelayanan, yaitu tangible, reponsivness, reliability, emphaty, dan assurance. Berdasarkan lima dimensi kualitas pelayanan tersebut, dimensi responsiveness merupakan dimensi dengan nilai mean terendah. Sedangkan dimensi assurance merupakan dimensi dengan nilai mean tertinggi.

Dimensi kualitas pelayanan yang pertama adalah dimensi tangible. Tangible merupakan ketersediaan fasilitas fisik, perlengkapan dan sarana komunikasi suatu layanan. Hasil dari dimensi tangible secara keseluruhan diperoleh nilai rata-rata sebesar 2,82 . Nilai tersebut berada pada rentang 2,52-3,26 sehingga kualitas dimensi tangible dapat dikategorikan baik. Nilai tersebut menunjukkan bahwa kualitas pelayanan 
yang dilakukan oleh pegawai bagian administrasi akademik dilihat dari aspekaspek tangible, seperti fasilitas, perlengkapan, dan penampilan personal secara fisik termasuk dalam kategori baik dengan standar deviasi $14,18 \%$. Hal tersebut menunjukkan bahwa sebagian besar responden menyatakan setuju bahwa administrasi akademik memiliki fasilitas fisik yang baik, perlengkapan yang cukup menunjang, serta pegawai yang berpenampilan rapi. Namun demikian, meskipun dimensi tangible ini dinilai sudah baik, tetapi masih belum sepenuhnya memenuhi harapan pelanggan. Hal ini dapat dilihat dari hasil jawaban dari pernyataan "Saya tahu kalau disana tersedia bagan/alur dari setiap pelayanan yang disediakan" memiliki nilai rata-rata 2,48 yang termasuk katagori buruk. Di samping itu, berdasarkan wawancara dengan sebagian mahasiswa, mereka menilai bahwa pelayanan peralatan dan fasilitas penunjang pembelajaran masih kurang baik, seperti kurangnya LCD projector dan perawatan peralatan yang lambat sehingga sebagian LCD projector tidak berfungsi. Dimensi ini erat kaitannya dengan penciptaan kesan pertama kepada pelanggan. Menurut Khan dan Fasih (2014: 335) "all organizations desire that their consumers get an exceptional and positive foremost impression. Focusing on this particular dimension will help them to gain maximum benefit". Untuk dapat menciptakan kesan pertama yang positif ini, aspek tangible merupakan hal yang sangat penting dalam membangun image tersebut. Jika kesan pertama yang dibangun positif, maka pelanggan akan merasa tidak sungkan untuk kembali lagi menggunakan layanan tersebut. Bahkan mereka akan dengan senang hati menyebarkan word of mouth yang positif atas layanan yang mereka terima tersebut. Maka dari itu, penting untuk lebih meningkatkan kualitas pelayanan yang bersangkutan dengan daya tanggap petugas dalam membantu pelanggan. Daya tanggap ini dapat ditingkatkan dengan menambah motivasi para petugas dalam memecahkan masalah yang dihadapi pelanggan dalam menggunakan jasa.

Dimensi yang kedua adalah dimensi responsiveness. Menurut Zeithaml (dalam Sitorus 2009) responsiveness merupakan kemauan atau keinginan para karyawan untuk membantu dan memberikan jasa yang dibutuhkan konsumen Dimensi ini diukur menggunakan dua indikator, yakni petugas selalu siap membantu permasalahan mahasiswa dengan sambutan dan petugas pelayanan menguasai tugas dan informatif. Dimensi ini merupakan dimensi yang dinilai memiliki kinerja paling rendah dibandingkan dengan dimensi-dimensi lainnya. Nilai mean dimensi responsiveness adalah sebesar 2,53. Nilai tersebut menunjukkan bahwa kualitas pelayanan yang dilakukan oleh pegawai akademik administrasi dinilai sudah baik. Meskipun demikian, hasil jawaban pernyataan "petugas selalu menyambut mahasiswa dengan senyuman" memiliki nilai rata-rata terendah yaitu 2,22 yang termasuk katagori buruk. Hal ini menunjukkan bahwa petugas dianggap kurang ramah dan siap untuk memberikan layanan kepada mahasiswa. Di samping itu, berdasarkan hasil wawancara masih terdapat keluhan mahasiswa, seperti keramahtamahan petugas yang masih kurang, kemudian mahasiswa yang datang ke BAAK tidak disambut dengan salam dan senyuman, serta mahasiswa sebagai konsumen kurang merasa diperhatikan dan dibantu. Menurut Hanaysha et al. (2014: 120) 
"The responsiveness dimension relates to the willingness of the company to assist its customers in providing them with a good, quality and fast service. It means that the employees are ready to help customers and respond to their demand as well as to notify customers when service is available.If a service fails to occur, then the ability to recover quickly and professionally is important as it will create very positive perceptions of services provider."

Berdasarkan pendapat tersebut dapat disimpulkan bahwa karena dimensi responsif ini berhubungan dengan kemauan perusahaan untuk membantu pelanggan dalam menyediakan layanan yang baik, berkualitas dan cepat, maka setiap karyawan harus siap membantu pelanggan dan menanggapi permintaan mereka sekaligus memberi tahu pelanggan kapan layanan tersedia. Jika layanan tidak dapat dilaksanakan atau sedang tidak tersedia, maka kemampuan untuk menyediakan layanan tersebut kembali cepat dan profesional sangat penting karena akan menciptakan persepsi yang sangat positif terhadap penyedia layanan.

Selanjutnya, dimensi yang ketiga adalah dimensi relaibility. Hasil dari dimensi reliability ini secara keseluruhan memiliki nilai mean sebesar 2,73 dengan standar deviasi dibawah $20 \%$. Hasil tersebut menunjukkan bahwa sebagian besar responden setuju bahwa kualitas pelayanan yang diberikan administrasi akademik di Polban memiliki keandalan yang baik. Keandalan pelayanan tersebut dapat terlihat dari bagaimana petugas selalu adil dalam melayani sesuai dengan urutan yang datang, jika terdapat info yang kurang jelas petugas bersedia untuk segera menyediakan dan menjelaskan informasinya, dan prosedur pelayanan yang diberikan mudah untuk diikuti. Namun, meskipun dimensi ini sudah dinilai baik tetapi masih belum sepenuhnya memenuhi harapan pelanggan. Berdasarkan hasil wawancara masih terdapat keluhan, seperti proses birokrasi yang panjang dan lambat, dimana prosedur pelayanan melalui tahapan yang panjang dan dilakukan dengan lambat sehingga memerlukan waktu yang cukup lama dalam penyelesaian suatu kegiatan. Selain itu, cara kerja petugas yang kurang sistematis, efesien, dan efektif, seperti dalam pengelolaan arsip sehingga ketika arsip itu dicari memerlukan waktu yang lama. Menurut Tjiptono (2009), keandalan merupakan kemampuan memberikan layanan yang dijanjikan dengan segera, akurat dan memuaskan. Artinya para karyawan memberikan pelayanan yang sesuai dengan harapan pelanggan. Menurut Khan dan Fasih (2014: 333) “customers want trustable services on which they can rely". Pelanggan menginginkan layanan terpercaya, yang dapat mereka andalkan. Jika layanan dirasa tidak dapat diandalkan, pelanggan pun akan merasa kecewa bahkan menghindari menggunakan layanan tersebut dikemudian hari. Oleh karena itu, pegawai administrasi akademik Polban harus lebih menunjukkan perhatian yang tulus kepada pelanggan dengan menepati janji, serta melayani dengan benar dan memilih kebijakan-kebijakan yang tepat tanpa mengesampingkan harapan pelanggan.

Dimensi yang keempat adalah emphaty. Menurut Zeithaml (dalam Sitorus 2009) emphaty meliputi sikap kontak personel maupun perusahaan untuk memahami kebutuhan maupun kesulitan, konsumen, komunikasi yang baik, perhatian pribadi, kemudahan dalam melakukan komunikasi atau hubungan. Nilai mean dari dimensi emphaty ini adalah sebesar 2,80 
yang menunjukkan bahwa kualitas pelayanan yang diberikan sudah dalam kategori baik. Nilai variansi dari dimensi ini pun menunjukkan angka dibawah $20 \%$, sehingga menunjukkan bahwa sebagian besar responden menyatakan setuju bahwa pegawai administrasi akademik di Politeknik Negeri Bandung memberikan kualitas pelayanan yang baik. Responden menilai para petugas sudah bersedia membantu ketika mendapatkan kesulitan saat meminta pelayanan, memberikan penjelasan yang mudah dimengerti, serta menyelesaikan pelayanan yang dibutuhkan sesuai dengan yang dijanjikan. Akan tetapi, pelayanan yang dilakukan oleh petugas masih belum sepenuhnya memenuhi harapan konsumen. Beberapa konsumen masih memberikan keluhan dari segi emphaty. Contohnya, dimana jam kerja petugas tidak sesuai dengan jadwal yang telah ditentukan. Petugas sering terlambat datang dan juga terlalu awal dalam istirahat, sedangkan dilain pihak mahasiswa tidak memiliki banyak waktu karena padatnya perkuliahan yang mengakibatkan proses pelayanan menjadi terhambat. Menurut Hanaysha et al. (2012: 120),

"Empathy refers to caring and individualized attention that the firm provides to its customers. This means, organization should understand the problem of customers and results must favor customers with individual personal attention. Empathetic organizations shouldn"t lose touch with customers. As such, empathetic organizations understand the needs of their customer and make their services accessible to them".

Berdasarkan hal tersebut, dapat disimpulkan bahwa empati mengacu pada perhatian dan atensi individual yang diberikan oleh perusahaan kepada pelanggan. Sehingga, organisasi harus memahami masalah pelanggan dan pada akhirnya harus mendukung pelanggan dengan memberikan perhatian pribadi kepada pelanggan. Organisasi yang memiliki empati tidak akan pernah mengabaikan interaksi sekecil apapun dengan pelanggan Dengan demikian, organisasi yang berempati akan memahami kebutuhan pelanggan mereka dan membuat layanan mereka dapat diakses oleh para pelanggan. Selain itu, menurut Delgado and Ballester (2004) "if the customers feel they get individualized and quality attention there is a very big chance that they will return to the company and do business there again." Mengingat pentingnya aspek emphaty ini, maka dari itu, penting bagi petugas untuk lebih memperhatikan kembali pelanggannya. Hal tersebut bisa dengan meninjau kembali kemudahan dalam menjalin relasi dan komunikasi yang baik, serta meningkatkan pemahaman atas kebutuhan individual para pelanggan yaitu dengan menunjukkan sikap pegawai yang tulus dalam melayani pelanggan.

Dimensi yang kelima adalah Assurance (Jaminan). Nilai mean dari dimensi ini adalah sebesar 2,83. Hasil tersebut menunjukkan bahwa keyakinan dan kemampuan petugas dalam membangun rasa percaya pelanggan terhadap pelayanan yang diberikan dinilai sudah baik. Menurut Tjiptono (2009), jaminan mencakup pengetahuan, kompetensi, kesopanan, dan sifat dapat dipercaya yang dimiliki para staf, bebas dari bahaya, risiko atau keraguan. Dimensi ini penting untuk diperhatikan, karena dengan adanya jaminan pengetahuan dan kompetensi yang baik para petugas atau pegawai dapat menangani segala kebutuhan dan keinginan pelanggan serta ketepatan 
penyampaiannya dalam mengimbangi harapan konsumen. Hal yang demikian dapat menimbulkan kepercayaan dimata pelanggan. Dimensi ini memiliki hubungan yang erat kaitannya antara pegawai dan pelanggan. Menurut Delgado dan Ballester (2004) "If the customers are not comfortable with the employees, there are a rather large chance that the customers will not return to do further business with the company." Jika pelanggan merasa tidak nyaman terhadap kinerja pegawai yang melayani, maka resiko pelanggan tersebut tidak akan kembali lagi dikemudian hari akan semakin tinggi.

\section{Kepuasan Pelanggan}

Pembahasan ini untuk menjawab tujuan penelitian yang kedua, yaitu tingkat kepuasan mahasiswa. Berdasarkan perhitungan SPSS, dapat diketahui bahwa nilai rata-rata kepuasan pelanggan layanan akademik Polban adalah sebesar 2,66. Nilai tersebut berada pada rentang 2,52-3,26 sehingga dapat dikategorikan baik. Standar deviasi pada variabel ini menunjukkan nilai variansi sebesar 17,25\% (0,459/2.66x100\%) atau berada dibawah $20 \%$, sehingga dapat disimpulkan bahwa jawaban responden terhadap variabel ini cukup seragam. Nilai mean terendah yakni sebesar 2,65 berada pada pernyataan kepuasan 1 dan 2 yakni, "saya senang dengan keseluruhan layanan administrasi akademik yang diberikan Politeknik Negeri Bandung", dan "saya percaya bahwa menggunakan pelayanan administrasi akademik biasanya/pada umumnya merupakan pengalaman yang memuaskan". Sedangkan pertanyaan dengan mean tertinggi yakni sebesar 2,69 berada pada pernyataan kepuasan 3 yakni "bila tingkat kepuasan dinilai dengan angka 1 s.d
4, maka kepuasan Saudara berada di nomor berapa?".

Menurut Yi dan La (dalam Osotimehin, 2015) ada dua konsep umum mengenai kepuasan yaitu kepuasan transaksi spesifik dan kepuasan kumulatif. Kepuasan transaksi spesifik merupakan evaluasi pelanggan atas pengalamannya terhadap layanan tertentu. Sedangkan kepuasan kumulatif mengacu kepada keseluruhan evaluasi pelanggan terhadap pengalamannya dalam mengunakan suatu jasa hingga saat ini. Secara keseluruhan, para mahasiswa merasakan manfaat lebih dengan adanya layanan administrasi akademik di Polban, sehingga tingkat kepuasan para mahasiswa dalam hal ini terbilang baik. Namun, bila di masa mendatang ada alternatif layanan administrasi akademik baru yang lebih praktis dan efisien, tidak menutup kemungkinan mahasiwa akan beralih menggunakan layanan tersebut dan tidak akan menggunakan layanan saat ini. Menurut Shauchenka \& Eugenia (2010) student satisfaction has become vital in helping universities move toward development and excellence; universities must listen to students to improve the worth and quality of student services. Selain itu, menurut Khan \& Fasih (2014: 348)

"The satisfaction of the customers is a very much important factor that not only forces the customers to remain loyal with the organization but also proves as a marketing mechanism through which other people are attracted towards the organization. The word of mouth of a satisfied customer probability has more worth than any other advertising channel."

Berdasarkan pendapat tersebut dapat disimpulkan bahwa kepuasan pelanggan sangat penting perannya, terutama dalam 
membangun loyalitas mahasiswa kedepannya. Bahkan dengan terciptanya kepuasan, hal tersebut bisa menciptakan mekanisme marketing melalui word of mouth yang tentunya akan menguntungkan institusi.

\section{Pengaruh Kualitas Pelayanan terhadap Kepuasan Pelanggan}

Berdasarkan hasil penelitian pada 100 orang mahasiswa dari semua jurusan yang ada di Politeknik Negeri Bandung diperoleh hasil bahwa terdapat hubungan antara variabel kualitas pelayanan dengan kepuasan pelanggan. Hal tersebut ditunjukkan dari hasil analisis korelasi dengan nilai sebesar 0,659 yang berarti terdapat hubungan positif yang kuat antara kualitas pelayanan dengan kepuasan pelanggan. Hal ini berarti bahwa semakin baik kualitas pelayanan yang dirasakan oleh pelanggan maka tingkat kepuasan pelanggan pun akan semakin baik.

Selain itu, berdasarkan analisis regresi yang dilakukan, didapatkan persamaan $\mathrm{Y}=0,831+0,130 \mathrm{X}$. Hasil tersebut menunjukkan bahwa setiap penambahan satu angka kualitas pelayanan dengan koefisien bernilai positif, maka kepuasan pelanggan akan meningkat sebesar 0,130. Sedangkan, apabila kualitas pelayanan sama dengan nol atau tidak ada perubahan, maka nilai kepuasan pelanggan sebesar 0,130.

Menurut Tjiptono (dalam Panjaitan dan Yulianti, 2016), kualitas pelayanan merupakan upaya pemenuhan kebutuhan dan keinginan konsumen serta ketepatan penyampaiannya dalam mengimbangi harapan konsumen. Sedangkan Kotler dan Keller (2009) mengungkapkan kepuasan adalah perasaan senang atau kecewa seseorang yang berasal dari perbandingan antara kesannya terhadap kinerja (atau hasil) suatu produk dan harapan harapannya. Maka dari itu, untuk mencapai kepuasan pelanggan perusahaan/organisasi perlu melakukan kesesuaian kualitas pelayanan dengan tingkat harapan pelanggan. Hal tersebut dikarena kualitas memberikan suatu dorongan kepada pelanggan untuk menjalin hubungan yang menghasilkan ikatan yang kuat dengan perusahaan/organisasi. Ikatan seperti ini memungkinkan perusahaan/organisasi untuk memahami dengan seksama harapan pelanggan serta kebutuhan mereka, sehingga dapat meningkatkan kepuasan pelanggan dengan cara memaksimalkan pengalaman pelanggan yang menyenangkan dan meminimalkan atau menghilangkan pangalaman pelanggan yang kurang menyenangkan.

Kualitas pelayanan berpengaruh terhadap kepuasan pelanggan. Menurut Saleh (2016: 42)

"The quality of university services is an important factor in determining student satisfaction; the higher the quality, the more content students are. Quality reflects the degree of effectiveness with which institutions provide products or services that meet students' expectations and needs".

Hal tersebut didukung dari hasil penelitian ini yang menunjukkan bahwa bahwa ke lima dimensi tersebut pembentuk layanan terbukti berpengaruh secara signifikan terhadap kepuasan pelanggan. Hasil penelitian ini menunjukkan bahwa 43,4\% kepuasan pelanggan bisa dijelaskan oleh kualitas pelayanan, sedangkan sisanya $(100 \%-43,4 \%)=56,6 \%)$ disebabkan oleh faktor-faktor lain yang tidak dijelaskan dalam penelitian ini. 


\section{KESIMPULAN DAN SARAN \\ Kesimpulan}

Berdasarkan hasil pembahasan dari bab-bab sebelumnya, maka dapat disimpulkan sebagai berikut:

1. Kualitas pelayanan administrasi akademik yang diberikan Politeknik Negeri Bandung terhadap mahasiswanya berada pada katagori baik. Hal ini ditunjukkan dari hasil nilai rata-rata dimensi tangible, reliability, responsiveness, assurance, dan emphaty berada pada katagori baik. Hasil nilai rata-rata dari setiap dimensi relatif sama. Dimensi yang memiliki nilai rata-rata tertinggi adalah assurance, sedangkan yang terendah adalah responsiveness. Namun demikian, masih ada yang dinilai buruk oleh mahasiswa, yaitu pada dimensi tangible tentang ketersedian alur/bagan dan pada dimensi responsiveness tentang kesiapan petugas menyambut mahasiswa yang memerlukan pelayanan.

2. Kepuasan mahasiswa terhadap pelayanan administrasi akademik yang diberikan Politeknik Negeri Bandung berada pada katagori baik.

3. Terdapat pengaruh yang positif dan signifikan antara kualitas pelayanan administrasi akademik yang diberikan Politeknik Negeri Bandung terhadap kepuasan mahasiswanya.

\section{Saran}

Walaupun secara keseluruhan kualitas pelayanan yang diberikan berada pada katagori baik dan kepuasan mahasiswa juga baik, namun masih perlu disarankan sebagai berikut:

1. Keramahtamahan petugas yang memberikan pelayanan administrasi akademik kepada mahasiswa hendaknya ditingkatkan lagi, seperti memberikan senyuman ketika menyambut mahasiswa yang akan meminta pelayanannya sehingga mahasiswa sebagai pelanggan merasa senang dan merasa diterima dengan baik.

2. Sebaiknya ada bagan/alur dari setiap pelayanan yang diberikan sehingga mahasiswa mengetahui apa yang harus dilakukan dalam meminta pelayanan tersebut.

3. Petugas hendaknya lebih disiplin lagi dalam hal waktu, baik sebelum maupun setelah jam istirahat agar mahasiswa yang memiliki waktu terbatas karena padatnya perkuliahan dapat dilayani dengan baik dan cepat.

4. Hendaknya setiap ruang kelas dilengkapi dengan LCD projector sehingga proses belajar mengajar dapat berjalan dengan baik. Di samping itu juga, perbaikan terhadap kerusakan alat tersebut agar dilakukan segera.

5. Mahasiswa sebagai pelanggan yang harus dilayani dengan sebaik mungkin, maka kualitas pelayanan yang diberikan Polban harus ditingkatkan lagi, bukan hanya baik tapi seharusnya sangat baik/pelayanan prima (excellent service).

\section{DAFTAR PUSTAKA}

Alfiani, A. (2016). Kepuasan Mahasiswa terhadap pelayanan Administrasi Akademik di Subbag Pendidikan. Yogyakarta: FIP UNY. 
Alma, B. (2011). Manajemen Pemasaran dan Pemasaran Jasa. Bandung: CV Alfa Beta.

Arikunto, S. (2010). Prosedur Penelitian: Suatu Pendekatan Praktik Edisi Revisi, Cetakan 14. Jakarta: Rineka Cipta.

Asaduzzaman, M., Hossain, M., \& Rahman, M. (2014). Service quality and student satisfaction: a case study on private universities in Bangladesh. International Journal of Economics, Finance and Management Sciences, 1(3), 128.

Daryanto \& Ismanto. (2014). Konsumen dan Pelayanan Prima. Yogyakarta: Gava Media.

Delgado-Ballester, E., Munuera-Aleman J. L. \&Yague-Guillen, M. J. (2004). Development and validation of a brand trust scale. International Journal of Marketing Research, 45(1), 35-53.

Fraenkel, J \& Wallen, N. (2008). How to Design and Evaluate Research in Education. New York, USA: McGraw-Hill Companies, Inc.

Ghozali, I. (2013). Aplikasi Analisis Multivariate dengan Program IBM SPSS 21. Semarang: Badan Penerbit Universitas Diponegoro.

Hanaysha, J. R., Dileep, K., \& Hilman, H. (2012). Service quality and satisfaction: Study on international students in universities of North Malaysia. International Journal of Research in Management, 3(2), 1163.

Ibrahim, A. (2008). Teori dan Konsep Pelayanan Publik serta Implementasinya. Bandung: Mandar Maju.
Irawan, B. (2012). Dimensi Kualitas Layanan: Konsep dan Perkembangannya. Jurnal ISEI Jember. Vol. 2 No. 1. Hal 95-108.

Khan, M. M., \& Fasih, M. (2014). Impact of Service Quality on Customer Satisfaction and Customer Loyalty: Evidence from Banking Sector. Pakistan Journal of Commerce \& Social Sciences, 8(2).

Kotler, P. (2007). Manajemen Pemasaran. Edisi 12 Jilid 1. Jakarta: PT Indeks

Kotler, P. \& Keller, K.L. (2009). Marketing Management $\left(13^{\text {th }}\right.$ ed). New Jersey: Prentice Hall, Inc. Diterjemahkan oleh: Bob Sabran. Jakarta: PT Gelora Aksa Pratama.

Kotler, P. \& Keller, K. L. (2009). Manajemen Pemasaran jilid 1, Edisi Ketiga Belas, Terjemahan Bob Sabran. Jakarta: Erlangga.

Malhotra, N. K. (2008). Riset Pemasaran: Pendekatan Terapan. Jakarta: Indeks Kelompok Gramedia.

Mardikawati \& Farida. (2013). Pengaruh Nilai Pelanggan dan Kualitas Layanan Terhadap Loyalitas Pelanggang Melalui Kepuasan Pelanggan Pada Pelanggan Bus Efisiensi. Jurnal Administrasi Bisnis. Vol 2, No. 1, Maret 2013.

Panjaitan J. R \& Yuliati A. L. (2016). Pengaruh Kualitas Pelayanan Terhadap Kepuasan Pelanggan Pada JNE Cabang Bandung. Jurnal Manajemen Vol 11 No. 2, September. Universitas Telkom

Priyatno, D. (2013). Mandiri Belajar Analisis Data dengan SPSS. Yogyakarta: Mediakom

Purwanto. (1995). Pengantar Statistika. Jakarta: Buku EGC. 
Rakhmat, J. (2004). Metode Penelitian Komunikasi:Dilengkapi contoh Analisis Statitstik. Bandung: PT Remaja Rosdakarya.

Riduwan. (2005). Belajar Mudah Penelitian untuk Guru-Karyawan dan Peneliti Pemuda. Bandung: Alfabeta.

Saleh, A. S. (2016). Using Service Quality to Measure the Satisfaction of Architecture Students at Private Jordanian Universities. International Review of Social Sciences and Humanities. Vol. 10, No. 2 (2016), pp. 40-49 www.irssh.com ISSN 2248-9010 (Online), ISSN 22500715

Santoso, S. (2010). Statistika Multivariat Konsep dan Aplikasi dengan SPSS. Jakarta: Elex Media Komputindo.

Sekaran, U. (2006). Metodologi Penelitian untuk Bisnis (jilid 1. Edisi 4). Jakarta: Salemba empat.

Shauchenka, H., \& Busłowska, E. (2010). Methods and tools for higher education service quality assessment (Survey). Zeszyty Naukowe Politechniki Białostockiej. Informatyka, 87-102.

Sugiyono. (2005). Metode Penelitian Administrasi. Bandung: $\quad \mathrm{CV}$ Alfabeta.

Sugiyono. (2007). Metode Penelitian Kuantitatif dan Kualitatif, $R \& D$. Bandung: Alfabeta.

Sugiyono. (2012). Metode Penelitian Kuantitatif, Kualitatif dan Kombinasi (mixed methods). Bandung: Alfabeta.

Sugiyono. (2013). Metode Penelitian Bisnis (Cetakan ke 17). Bandung: Alfabeta.

Sugiyono. (2013). Metode Penelitian Kombinasi (Mixed Methods). Bandung: Alfabeta.
Sunyoto, D. (2014). Konsep Dasar Riset Pemasaran dan Perilaku Konsumen. Yogyakarta: CAPS (Center for Academic Publishing Service).

Tjiptono, F. \& Chandra, G. (2011). Service, Quality \& Satisfaction. Yogyakarta: Andi.

Tjiptono, F. (2005). Pemasaran Jasa. Yogyakarta: BPFE.

Tjiptono, F. (2008). Manajemen Jasa. Yogyakarta: Andi.

Tjiptono, F. (2009). Service Marketing: Esensi dan Aplikasi. Yogyakarta: Marknesis

Planet Semantic (2011). "Tips Membuat Skala Likert". Di unduh tanggal 24 April 2017 pada http://www.consultanthr.com/psycho metrics/test-types/2008/04/23/tipsmembuat-skalalikert\#sthash.ttFn5bLR.dpuf. 